\title{
Acute Respiratory Distress Syndrome Caused by Rhinovirus
}

\section{Rinovirüsün Neden Olduğu Akut Respiratuvar Distres Sendromu}

\author{
Gökhan Ceylan', Rana Işgüder', Ahu Kara², Gamze Gülfidan³, Hasan Ağın', İlker Devrim² \\ ${ }^{1}$ Pediatric Intensive Care Unit, Dr. Behcet Uz Pediatric Diseases and Surgery Training and Research Hospital, Izmir, Turkey \\ 2 Pediatric Infectious Diseases Unit, Dr. Behcet Uz Pediatric Diseases and Surgery Training and Research Hospital, Izmir, Turkey \\ ${ }^{3}$ Clinic of Infectious Diseases and Clinical Microbiology, Dr. Behcet Uz Pediatric Diseases and Surgery Training and Research Hospital, Izmir, Turkey
}

\begin{abstract}
The majority of cold and flu-like illnesses are caused by rhinoviruses. However rhinoviruses are also associated with more serious illness, such as exacerbation of asthma, wheezing, chronic obstructive pulmonary disease and fatal pneumonia in immunocompromised patients. Human rhinovirus is a major cause of acute viral respiratory tract infections in hospitalized children. In this article we present a 3-month-old girl who was admitted to our pediatric intensive care unit with complaints of difficulty in breathing and severe pneumonia. During her treatment for pneumonia caused by rhinovirus infection acute respiratory distress sydrome was onset so she was supported with mechanical ventilation for 18 days. After total treatment of three weeks, patient was discharged without any sequela.
\end{abstract}

Keywords: Rhinovirus, acute respiratory distress syndrome, bronchoalveolar lavage, severe pneumonia, ARDS

\section{Introduction}

In general, rhinoviruses have been known as a common cold agent for a long time, and are characterized by a mild, moderate and self-limiting infection pattern. In recent years, rhinoviruses have been shown to cause lower respiratory tract infections and induce asthma attacks in both adults and
Özet

Soğuk algınlığı ve grip benzeri hastalıkların çoğu rinovirüslerden kaynaklanmaktadır. Bununla birlikte rinovirüsler, astım ataklarının alevlenmesi, hışıltı, kronik obstrüktif akciğer hastalığı (KOAH) ve bağışıklık sistemi baskılanmış hastalarda fatal pnömoni gibi daha ağır tablolar ile de ilişkilidir. Rinovirüsler, hastanede yatan çocuklarda akut viral solunum yolu enfeksiyonlarının önemli bir nedenidir. Bu makalede nefes almakta zorluk şikayeti ile başvuran ve ağır pnömoni tanısıyla yatırılan üç aylık bir kız çocuğu sunulmaktadır. Hastada rinovirüse bağlı pnömoni tanısı ile izlenirken akut respiratuvar distres sendromu (ARDS) gelişti ve 18 gün süreyle mekanik ventilatörde izlendi. Toplam üç hafta süren tedavi sonrasında hasta sekelsiz olarak iyileşti.

Anahtar Kelimeler: Rinovirüs, akut respiratuvar distres sendromu, bronkoalveoler lavaj, ağır pnömoni, ARDS

children (1). Mortalities caused by rhinovirus-induced severe pneumonia in Vietnamese children show that rhinoviruses may also cause severe infections, although rare (2).

In this article, we present a three-month-old female patient with rhinovirus-induced acute respiratory distress syndrome (ARDS). 


\section{Case Report}

A three-month-old female patient was admitted to the emergency department with complaint of difficulty in breathing. It was learnt that she had fever, cough, and nasal discharge that started a week ago, and that the complaints of the patient had increased, and she was referred to our hospital from an external center due to the development of wheezing while breathing. The patient was having azithromycin and ampicillin treatment for a week, and her medical history included that she was hospitalized in the pediatric infectious diseases service for 8 days due to measles infection a month prior. In the first physical examination of the patient, the general condition was moderate-bad, patient was conscious, and hydration was sufficient. Body weight was $3500 \mathrm{~g}(<3 \mathrm{p})$, height was $59 \mathrm{~cm}(25-50 \mathrm{p})$, the head circumference was 38 $\mathrm{cm}$ (3-10 p), pulse was 130 beat/minute, blood pressure was $105 / 55 \mathrm{mmHg}$, and respiratory rate was $66 /$ minute. Bilateral diffuse crepitant rales were heard, and it was accompanied by tachycardia. A large amount of serous nasal discharge was detected in the patient. In the bloodwork of the patient, hemoglobin was $11.6 \mathrm{~g} / \mathrm{dL}$, hematocrit was $36.7 \%$, white blood cell count was $9700 / \mathrm{mm}^{3}$ (62\% leukocyte with polymorphic nuclei, $38 \%$ lymphocyte), thrombocyte was $738.000 / \mathrm{mm}^{3}$, C-reactive protein was $0.32 \mathrm{mg} / \mathrm{dL}$, and procalcitonin was < $0.05 \mathrm{ng} / \mathrm{mL}$. Patient was admitted to pediatric intensive care clinic with an initial diagnosis of pneumonia. Bilateral paracardiac infiltration was detected in the first chest $x$-Ray of the patient, and ceftriaxone $100 \mathrm{mg} / \mathrm{kg} /$ day was started intravenously with two doses. Non-invasive ventilation (CPAP) was started since the respiratory distress increased on the second day of the hospitalization, and $\mathrm{PaO}_{2} / \mathrm{FiO}_{2}$ was found to be 340 in the blood gas. However, the general condition of the patient worsened (respiratory distress that started in the last week, opacities not associated with the effusion or atelectasis in chest $\mathrm{x}$-Ray, confirmation that the pulmonary edema was not cardiac origin through echocardiography, $\mathrm{PaO}_{2} /$ $\mathrm{FiO}_{2}$ was found to be 104 in arterial blood gas) and ARDS did not meet the Berlin criteria, the patient was intubated, and then connected to the mechanical ventilator (Figure 1). The antibiotic treatment received by the patient was changed to $60 \mathrm{mg} / \mathrm{kg} /$ day of vancomycin and $15 \mathrm{mg} / \mathrm{kg} /$ day of clarithromycin. According to the result of multiplex PCR performed on bronchoalveolar lavage (BAL) for viral agents, rhinovirus was detected as positive whereas other possible factors such as Influenza $A / B$, coronavirus, metapneumovirus $A / B, R S V A / B$, enterovirus, parechovirus, bocavirus, adenovirus, Mycoplasma pneumoniae, Chlamydia pneumoniae, Staphylococcus aureus, Streptococus pneumonia, and Haemophilius influenza, which were scanned by this method, were found to be negative. No bacterial growth was observed in blood cultures obtained

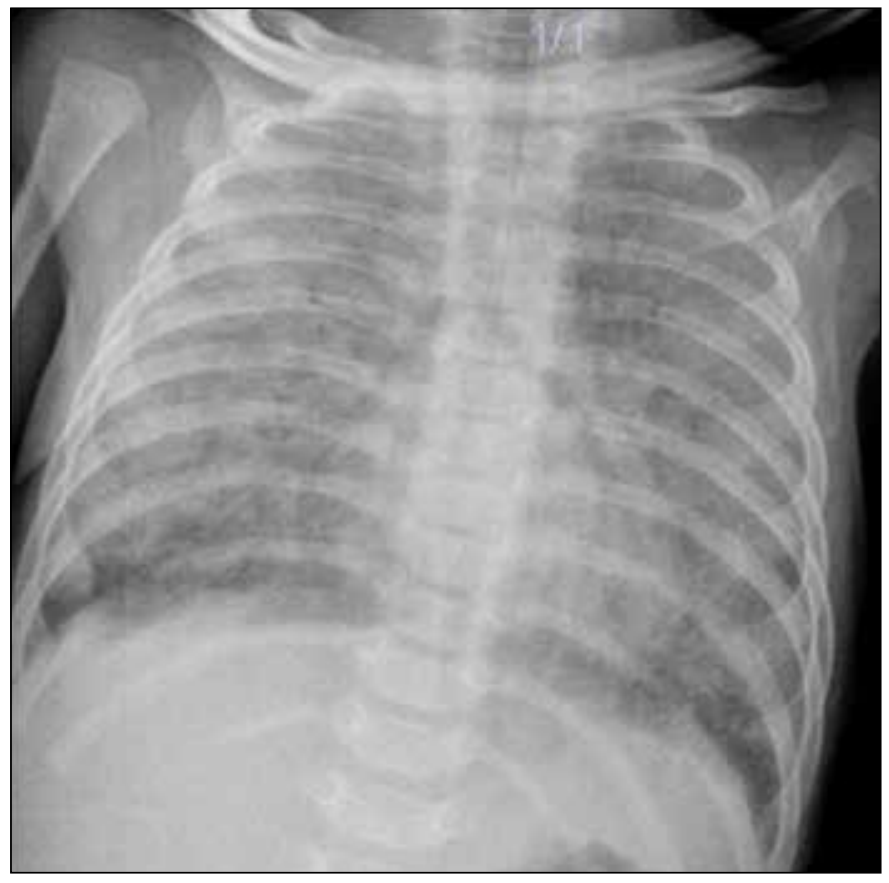

Figure 1. Posteroanterior (PA) chest radiography at the time of diagnosis of ARDS (bilateral spreading opacities, which obscure heart contour, are being observed at all lung areas).

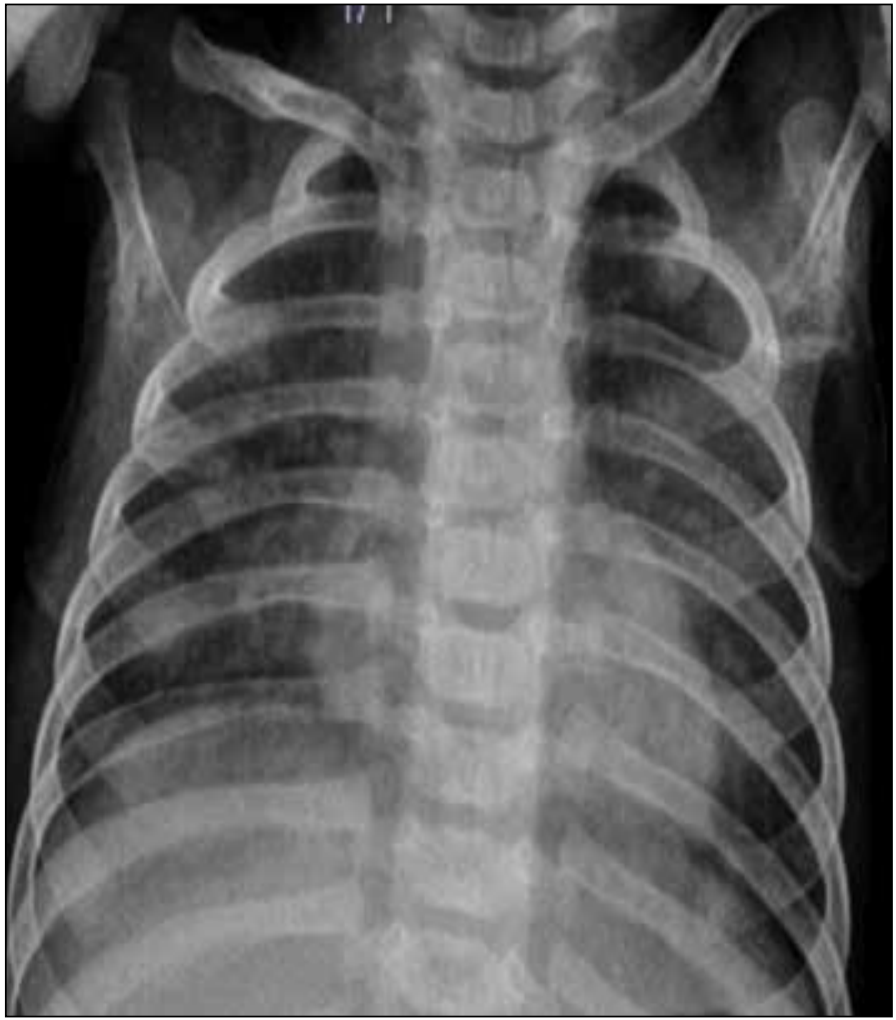

Figure 2. PA chest radiography taken after extubation (opacities observed during ARDS and not associated with atelectasis are lost, the heart contour has become apparent again). 
during this period and BAL cultures obtained by mini-BAL method. Spontaneous respiration of the patient was successful, and the patient was extubated on the $19^{\text {th }}$ day of the hospitalization (Figure 2). Antibiotic treatment of the patient was completed within 21 days, and the patient was discharged following recovery. No pathology was found during the monthly follow-up visits.

\section{Discussion}

Rhinoviruses are often known as viral infectious agent. In general, they are characterized by mild, moderate and self-limiting infections. Rhinovirus infects mainly bronchial epithelial cells (3). In a previous study, rhinovirus infections were researched and the most common presentation was shown to be acute bronchiolitis, however, it was shown to cause fewer hospitalizations compared with respiratory syncytial virus (RSV) (4). Interferon beta levels of the children with a history of rhinovirus infection were found to be decreased in their next rhinovirus infections (5). A significant increase in the production of TNF- $a$ and IL-8 has been shown when alveolar macrophages, which are the most important parts of the immunity in the lungs, are infected with rhinovirus. This increase is thought to be one of the mechanisms triggering the asthma attack (6).

In recent studies, rhinovirus infections have been shown to not only lead to mild results, but also to the ARDS as it is shown in our case. In an article reported from Vietnam, detection of rhinovirus in 12 children, who were hospitalized due to severe lower respiratory tract infection between December 2007 and February 2008, supports our cause. Furthermore, despite of the use of mechanical ventilation and broad-spectrum antibiotics during an outbreak in Vietnam, the death of seven of the 12 children who developed ARDS, shows that the disease can be severe (2).

In a retrospective study of 93 cases from the United States, the cases with severe lower respiratory tract findings and rhinovirus infection were evaluated, and $82 \%$ of the cases were reported to be younger than 12-months-old (7). Similarly, the fact that all cases hospitalized during the outbreak in Vietnam were 2 to 4 months old children and our case was at a young age made us think that particularly young children are at risk. Although mechanical ventilation and broad-spectrum antibiotics were used during the outbreak in Vietnam, seven of the 12 children, who developed ARDS, were reported to have died. One of the most important characteristics of these cases is that they lived in an orphanage and had a low body weight (2). The low weight percentages of our case also support the argument that nutritional status plays an important role in the severe course of rhinovirus infections. Although no abnormality was detected in metabolic examinations and immunologic examinations performed in our case, the measles infection, which was had one month ago, was thought to cause the transient immunosuppression by suppressing the T-cell response, and thus the severe rhinovirus infection, and therefore, it was thought to be the basis for the development of ARDS (8). Due to the same reason, the antibiotic treatment received by the patient was continued after the rhinovirus was detected as the causative agent. In a study carried out in USA, the presence of underlying diseases (prematurity, congenital heart disease, reactive airway disease) in the $69 \%$ of children with rhinovirus-induced severe lower respiratory tract infections shows the importance of comorbidity (7).

According to Berlin criteria, our case was considered as ARDS developed on the ground of rhinovirus (9). Low tidal volume ventilation (LTVV) $(6 \mathrm{~mL} / \mathrm{kg})$ was preferred in our patient. In a multi-center study, LTVV has been shown to reduce both mortality and ventilator length of stay compared to conventional mechanical ventilation (10). Although, theoretically, it has been stated that performing high frequency breathing to provide minute ventilation in LTVV can create air trapping (auto-PEEP) by inhibiting the completion of expiration, we did not observe auto-PEEP in our case which is incompatible with the results of multicenter ARMA study comparing LTVV with conventional ventilation $(10,11)$. The high PEEP strategy avoids cyclic atelectasis during ventilation and improves oxygenation (11). Alveolar overvoltage and cyclic atelectasis are the main causes of ventilator-associated pulmonary damage (12). In patients to whom high PEEP is applied, cyclic atelectasis does not occur as the alveoli do not close, and alveolar overvoltage is prevented, as each tidal volume (TV) is shared by all open alveoli (12). In a meta-analysis including 2299 patients with ARDS, which was carried out in 2010, the use of high PEEP has been shown to improve oxygenation, to increase ventilator independent days and to reduce the need for prone position-like support maneuvers (13). Incompatible with the literature, no support maneuvers were needed for our patient, to whom LTVV and high PEEP were performed, and she was successfully extubated. In a case reported in our country, our case was evaluated through echocardiography as the development of rhinovirus-induced pericardial effusion has been reported not to recover the respiratory distress of the patient despite of the appropriate treatment; however, no pathology was observed (14).

In conclusion, it should be kept in mind that human rhinovirus infections may cause severe lower respiratory tract infections, and even ARDS. It should be remembered that rhinovirus infections may be severe, particularly in younger children and in children under the age of 12 months with underlying disease. 
Informed Consent: Written informed consent was obtained from the parents of the patient.

Peer-review: Externally peer-reviewed.

Author Contributions: Concept - GC; Design - HA, GC; Supervision - HA; Data Collection and/or Processing - Ri; Analysis and/or Interpretation - ID; Literature Review: ID, GG; Writing - GC, ID; Critical Review - iD.

Conflict of Interest: No conflict of interest was declared by the authors.

Financial Disclosure: Authors declared that this study was not financially supported.

\section{References}

1. Heymann PW, Platts-Mills TA, Johnston SL. Role of viral infections, atopy and antiviral immunity in the etiology of wheezing exacerbations among children and young adults. Pediatr Infect Dis J 2005;24 (Suppl 11):S217-22. [CrossRef]

2. Hai le T, Bich VT, Ngai le K, et al. Fatal respiratory infections associated with rhinovirus outbreak, Vietnam. Emerg Infect Dis 2012;18:1886-8.

3. Papadopoulos NG, Bates PJ, Bardin PG, et al. Rhinoviruses infect the lower airways. J Infect Dis 2000;181:1875-84. [CrossRef]

4. McMillan JA, Weiner LB, Higgins AM, Macknight K. Rhinovirus infection associated with serious illness among pediatric patients. Pediatr Infect Dis J 1993;12:321-5. [CrossRef]

5. Wark PA, Johnston SL, Bucchieri F, et al. Asthmatic bronchial epithelial cells have a deficient innate immune response to infection with rhinovirus. J Exp Med 2005;201:937-47. [CrossRef]
6. Oliver BG, Lim $S$, Wark $P$, et al. Rhinovirus exposure impairs immune responses to bacterial products in human alveolar macrophages. Thorax 2008;63:519-25. [CrossRef]

7. Kim JO, Hodinka RL. Serious respiratory illness associated with rhinovirus infection in a pediatric population. Clin Diagn Virol 1998;10:57-65. [CrossRef]

8. Griffin DE, Bellini WJ. Measlesvirus. In: Fields' virology. Fields BN, Knipe DM, Howley PM. Philadelphia: Lippincott-Raven, 1996:1267.

9. ARDS Definition Task Force, Ranieri VM, Rubenfeld GD, et al. Acute respiratory distress syndrome: the Berlin Definition. JAMA 2012;307:2526-33. [CrossRef]

10. Acute Respiratory Distress Syndrome Network, Brower RG, Matthay MA, et al. Ventilation with lower tidal volumes as compared with traditional tidal volumes for acute lung injury and the acute respiratory distress syndrome. N Engl J Med 2000;342:1301-8. [CrossRef]

11. de Durante $G$, del Turco $M$, Rustichini $L$, et al. ARDS Net lower tidal volume ventilatory strategy may generate intrinsic positive endexpiratory pressure in patients with acute respiratory distress syndrome. Am J Respir Crit Care Med 2002;165:1271-4. [CrossRef]

12. Caironi P, Cressoni M, Chiumello D, et al. Lung opening and closing during ventilation of acute respiratory distress syndrome. Am J Respir Crit Care Med 2010;181:578-86. [CrossRef]

13. Briel $M$, Meade $M$, Mercat $A$, et al. Higher vs lower positive endexpiratory pressure in patients with acute lung injury and acute respiratory distress syndrome: systematic review and meta-analysis. JAMA 2010;303:865-73. [CrossRef]

14. Kanik-Yuksek S, Tezer H. Pericardial effusion associated with rhinovirus infection in an immunocompetent infant. Indian Pediatr 2014;51:8378. [CrossRef] 